$\begin{array}{ll}\text { Variants } & \begin{array}{l}\text { Variants } \\ \text { The Journal of the European Society for Textual } \\ \text { Scholarship }\end{array}\end{array}$

$12-13$ | 2016

Varia

\title{
Catherine Rovera, Genèses d'une folie créole: Jean Rhys et Jane Eyre
}

\section{Christine Collière-Whiteside}

\section{(2) OpenEdition \\ Journals}

Electronic version

URL: http://journals.openedition.org/variants/395

DOI: 10.4000/variants.395

ISSN: 1879-6095

\section{Publisher}

European Society for Textual Scholarship

\section{Printed version}

Date of publication: 31 December 2016

Number of pages: 257-260

ISSN: 1573-3084

\section{Electronic reference}

Christine Collière-Whiteside, «Catherine Rovera, Genèses d'une folie créole: Jean Rhys et Jane Eyre », Variants [Online], 12-13 | 2016, Online since 01 May 2017, connection on 23 September 2020. URL : http://journals.openedition.org/variants/395 ; DOI : https://doi.org/10.4000/variants.395

This text was automatically generated on 23 September 2020.

The authors 


\title{
Catherine Rovera, Genèses d'une folie créole: Jean Rhys et Jane Eyre
}

\author{
Christine Collière-Whiteside
}

\section{REFERENCES}

Catherine Rovera. Genèses d'une folie créole: Jean Rhys et Jane Eyre. Paris: Hermann Éditeurs, 2015. 159 pp. ISBN-13 978-2705690465.

1 In Genèses d'une folie créole:Jean Rhys et Jane Eyre, Catherine Rovera does not offer yet another intertextual study of Jean Rhys's rewriting of Jane Eyre, as the title of her book might suggest; instead, she succeeds in shedding new light on Wide Sargasso Sea, drawing from works published earlier by Rhys, unpublished letters, various drafts for Wide Sargasso Sea as well as working documents of other texts such as Voyage in the Dark, or the poem "Obeah Night", for instance. She skillfully combines different approaches, using close text analysis, genetic study of the drafts and research into the historical background of both novels and into the circumstances of their writing, thus going beyond previous postcolonial, feminist or postmodernist readings of the novel. In particular, she draws from numerous letters, personal papers and drafts from the Jean Rhys Archive in the McFarlin Library at the university of Tulsa (Oklahoma) and from the genetic documents kept at the British Library.

In this short book, Rovera pieces together a very dense, in-depth analysis, leaving no loose ends, and she constantly manages to draw connections between all the different tracks she explores, making for a fascinating read. The first part of the book mainly concentrates on the West Indies and on the beginnings of the genesis of the book, while the second part addresses more specifically the relationship with the Victorian subtext and the final stages of the writing of the novel.

3 In the first part, she shows how Wide Sargasso Sea, a novel that was thirty years in the making, is a reworking of some of Rhys's own previous fictional and semiautobiographical texts before being a rewriting of Charlotte Brontë's novel: she goes 
back to the lost manuscript of "Creole", to the earliest remaining document linked to Wide Sargasso Sea, dated 1938 and entitled "Mr Howard's House" and to the "Black Exercise Book", as well as drawing on several other manuscripts, such as the lost story "Le revenant" or the novel Voyage in the Dark, to understand the intricate relationship between the text, its "avant-textes" and its hypotext, Jane Eyre. The drafts for Wide Sargasso Sea proper, kept at the British Library, mainly concern Part II of the novel and the last stages of its writing (1961-64), so that Rhys's correspondence proves particularly useful. It provides information on the writing of part I and III, and testifies to Rhys's desire to write a historical novel and to the extensive research work she conducted on the history and legends of the West Indies, thus allowing Catherine Rovera to unveil echoes of texts other than Jane Eyre in Rhys's text. She thus describes an "écriture à processus", in which the author appears not to be in control of her creation, which takes her to places she had not planned to go.

Working on the sources of Wide Sargasso Sea allows Rovera to explore the complex meanings of the word "creole", its successive definitions and uses throughout the history of the West Indies, and the consequences of that troubled history on the heroine's racial and social status. She demonstrates how the figure of the creole woman is inextricably mixed with that of the Haitian myth of the zombie, of African origin, and its European variant, the vampire, but also with the stories of the rebel slaves, and how this character is best defined, in short, as defying any attempt at labeling or categorizing her. Rovera unravels the complex mesh of voices that the text is made of and allows us to hear the echoes of the historical source texts Rhys read. She shows how they shape Rochester's discovery of the West Indies as a conqueror or as an explorer, which parallels his relationship with Antoinette as he sets on a quest for the truth about both the island and his wife's past and origins. She studies the status of the creole language in the novel, the importance of orality, characterized by the use of different languages -English, French, patois - and the role it plays in the development of the themes of manipulation, contamination, mimicry and alienation, purity and hybridity, plagiarism and pastiche. This leads her to show the intricacy of the interplay of voices and points of views, and in particular the power of the voices of Christophine and Daniel, possessing Rochester through music, songs, poetry and voodoo magic.

In the second part of the book, the author explores the influence of the Victorian stage and art as well as the Gothic novel on the visual aesthetics of Jane Eyre and how much Brontë's novel owes to Victorian melodrama, peep shows, freak shows, magic and orientalism. Rhys's correspondence sheds light on the process which led her to give flesh and voice to the character of Bertha Mason and how this process was both deeply rooted in her reading of Jane Eyre and departing from it. It allows one to understand how the author was drawn to attempt to explain the origins of Bertha's madness, creating a background of traumatic childhood experiences for her heroine, using interior monologue to convey dreams, memories and predictions or hallucinations which turn the novel into a clinical and psychoanalytical study of Antoinette's supposed folly. Rovera explains how Rhys gradually introduces madness into the novel and relates it to a crisis of identity linked to the loss of a place. The correspondence bears evidence to Rhys's search for the right technique to create Bertha's voice, a voice coming from nowhere and no one, a ghost or zombie voice that finally contaminates Rochester. It allows Rovera to establish the crucial role played by the writing of the poem "Obeah night" and by Rhys's return to Caribbean oral literature in shaping the character of Rochester, from a cold and calculating villain to a more romantic, 
wounded character, the victim of a poetic trance that echoes that of Othello, thus allowing Rhys to feel that the book had finally found its proper shape. Looking at the drafts enables Rovera to have a fresh take on the relationship between Jane Eyre and Wide Sargasso Sea, to show how Jean Rhys kept going back to Jane Eyre and immersed herself in it to the extent that her writing became haunted by Brontë's text as phrases from Jane Eyre kept creeping into it unawares, while constantly distancing herself from it at the same time.

6 It is a pity no facsimiles of Rhys's manuscript drafts could be included in the book, as they both allow Catherine Rovera to reconstitute the chronological story of the writing of the book while giving us a glimpse of the simultaneous potential paths the text could have taken at every step. The gorgeous 16th century map of the West Indies that is reproduced on the cover aptly mirrors the richly-detailed study it contains and reminds the reader that this study maps out a wider territory than the merely textual genesis of a novel.

\section{AUTHORS}

\section{CHRISTINE COLLIÈRE-WHITESIDE}

Christine Collière-Whiteside holds a PhD in English literature from the Sorbonne Nouvelle in Paris and is a lecturer at the Universite de Bourgogne. She worked on the genesis of the Sylvie and Bruno books and the collaboration between Carroll and Furniss, and is currently working on the manuscripts of George MacDonald's Lilith and the Roald Dahl papers. She's a member of the Centre Interlangues-TIL lab and an associate researcher with the ITEM-CNRS Joyce team on the Finnegans Wake notebooks. Her research interests include critique génétique, children's literature and the didactics of foreign languages. 